\title{
Complementarity in Rubber-Salacca Intercropping System Under Integrated Fertilization Mixed with Organic Soil Amendments
}

\author{
Zar Ni Zaw ${ }^{1}$, Rawee Chiarawipa ${ }^{1 *}$, Surachart Pechkeo ${ }^{1}$ and Sakanan Saelim ${ }^{2}$ \\ ${ }^{1}$ Agricultural Innovation and Management Division, Faculty of Natural Resources, Prince of Songkla University, \\ Songkhla, 90112, Thailand \\ ${ }^{2}$ Faculty of Technology and Community Development, Thaksin University, Phatthalung 93110, Thailand
}

\begin{abstract}
The replanting practice of rubber monocropping in Southern Thailand has depleted soil fertility. Most rubber planted areas in the region were under intensive chemical fertilization resulting in less soil organic matters and root proliferation. With the instability of rubber prices, some rubber farmers converted from monocropping into intercropping. Integrated fertilization in which mixed organic-inorganic fertilizers are combined with organic soil amendments could be considered in a rubber-based intercropping system to increase land productivity with cost-saving fertilization by rehabilitating soil properties. A study was conducted at a rubber-salacca intercropping farm comprised of 14-year-old mature rubber trees associated with eight-year-old salacca palms to identify the consequences of the integrated fertilization combined with two organic soil amendments: humic acid (HSA); chitosan (CSA). Changes in soil organic matter (SOM), leaf area index (LAI), fine root traits, tree physiological status, and crop productions under the two integrated fertilization were compared against the controlled application of conventional chemical fertilizer. The CSA application increased the SOM in the

ARTICLE INFO

\section{Article history:}

Received: 14 July 2021

Accepted: 22 November 2021

Published: 24 January 2022

DOI: https://doi.org/10.47836/pjtas.45.1.09

E-mail addresses:

6110630008@psu.ac.th (Zar Ni Zaw)

rawee.c@psu.ac.th (Rawee Chiarawipa)

surachart.p@psu.ac.th (Surachart Pechkeo)

sak-a-nan.s@tsu.ac.th (Sakanan Saelim)

*Corresponding author

topsoil layer by $80 \%$. In the $21-40 \mathrm{~cm}$ soil depth, the rubber roots treated with HSA and the salacca palm roots treated with CSA showed greater fine root length density (FRLD). Under CSA, the physiological status of the rubber trees showed less stress. The treatments of HSA and CSA showed $145 \%$ and $72 \%$, respectively, higher in total production of salacca palm than that of the
\end{abstract}


chemical fertilization. Improvements in the soil fertility, the root's function, the crops' yields, and the tree physiological status were consequences as complementarity in the system under the integrated fertilizations.

Keywords: Chitosan, Hevea brasiliensis, humic acid, intercropping, integrated fertilization, soil amendment

\section{INTRODUCTION}

Most natural rubber (Hevea brasiliensis) growing areas in Southern Thailand are currently in the second or third replanting cycle of rubber monocropping. This replanting practice of the same perennial monocrop has depleted soil fertility substantially (Umami et al., 2019; VrignonBrenas et al., 2019). Besides, about $67 \%$ of the region's rubber growing area was under intensive application of chemical fertilizer (National Statistical Office, 2013) to meet targeted immature period and economic yield. Its long-term application accumulated adverse effects on soil structure, such as soil acidification, soil water pollution, and soil organic matter shortage - consequently, root functions like less root proliferation and nutrient-uptake activities.

In the last two decades, due to the instability of rubber prices, some rubber farmers in the area started converting into intercropping to widen the on-farm income sources and increase land productivity (Hougni et al., 2018; Romyen et al., 2018). In the area, most rubber-based intercropping farms were transformed from mature monocropping rubber farms and mostly intercropped with perennial cash crops like bamboo, coffee, cacao, ginger, and salacca anticipation long-term economic benefits (Jongrungrot et al., 2014). However, some combinations of rubber-based intercropping experienced adverse effects on the growth and yield of the crops due to some competitions in root interactions and nutrient uptakes (Langenberger et al., 2017). Thus, in these types of permanent rubber-based intercropping, complementarity interactions in the system are the main consideration in which the crops and other components are facilitative complements each other to achieve ecological benefits together with healthy physiological status of the crops and vegetative growth, ensuring sustainable crop yields for long-term economic benefits (Bybee-Finley \& Matthew, 2018).

Since rubber tree transforms sucrose into natural rubber, cis polyisoprene, as a product of the tree's defense mechanism in response to human interventions (latex harvesting) and environmental conditions, the healthy physiological status of the tree plays a crucial role in natural rubber production (Adou et al., 2017; Obouayeba et al., 2011). Biochemical compositions, mainly sucrose (Suc), inorganic phosphorus (Pi), and reduced thiols (R-SH) contents, are analyzed to evaluate the physiological status and yield potential of rubber trees (Christophe et al., 2018). As the sucrose are transformed into rubber molecules in the laticiferous system, high Suc content in the rubber latex indicates less sucrose utilization in the defense mechanism. Overexploitation in latex harvesting significantly reduces 
the Suc content in the latex, reflecting the high stress of the physiological status of the tree (Doungmusik \& Sdoodee, 2012). The Pi represents the main constituent of the energy metabolism in the laticiferous system and exhibits the level of sucrose utilization and intensity of biosynthetic activity. Atsin et al. (2016) reported that $\mathrm{Pi}$ content was positively associated with the active metabolism; thus, a higher Pi indicated a significant yield potential under healthy rubber trees. The reduced thiols are important antioxidants to protect the laticiferous cells in the defense mechanism and reduce oxidative stresses mainly caused by latex harvesting (Purwaningrum et al., 2019). Low R-SH content in the latex indicates high physiological stress of the laticiferous system.

According to the principle of integrated nutrient management, harmonious utilization of farm nutrient sources such as organic manure and farm wastes, mixed with inorganic fertilizers could be considered an integrated fertilizer (Food and Agriculture Organization of the United Nations [FAO], 2016) in the rubber-based intercropping system to increase land productivity with cost-saving fertilization through improvement or rehabilitation of soil properties.

One of the integrated usages of available farm wastes, humic acid extracted from vermicompost of biodegradable farm wastes like animal manures, green manures, and crop residues, has been widely applied as an organic soil amendment (Selladurai \& Purakayastha, 2016). It enhances microbial activities and a population that transform insoluble mineral nutrients into available nutrient form for plant in the soil, thus higher soil nutrient content (Li et al., 2019). In humic acid-treated soil, $\mathrm{pH}$ buffering capacity, organic matter, and cation exchange capacity were improved with more significant soil physical properties resulting in enhanced root performances like fine root proliferation and nutrient uptake (Buyukkeskin et al., 2015; Cahyo et al., 2014). It was reported that the growth rates of nursery and immature rubber plants were enhanced by reducing chemical fertilizer usages and supplementing a humic acid application (Dharmakeerthi et al., 2013). Likewise, chitin and chitosan processed from chitin-containing wastes from the fishery industry, available in the area, have been widely applied as a natural plant elicitor. Chitosan-treated plants improved pathogen resistance because of their antimicrobial properties and defense mechanism (Sharp, 2013). With improved plant metabolism, vegetative growth of plant and crop yield were significant under chitosan application in combination with chemical fertilizer (Y. C. Chen et al., 2016).

Although the sources for these organic soil amendments are available in the area, their usages have not been found yet in the rubber farms and rubber-based intercropping. Furthermore, studies related to the integrated fertilizations in rubber-based intercropping systems are also limited in the scientific literature. Thus, an experiment was conducted at a mature rubber-intercrop farm to investigate 
the consequences of the agroecosystem components' interactions under integrated fertilizer applications combined with different organic soil amendments compared to conventional chemical fertilization.

\section{MATERIALS AND METHODS}

A mature rubber farm intercropped with salacca palm (Salacca zalacca) situated at 6'59'46.9'N, 100³4'58.6'"E in Na Mom district, Songkhla province, Southern Thailand, was selected for the experimental study. The area receives an annual rainfall of about 2,000 $\mathrm{mm}$ distributed from June to December. In general, monthly rainfall precipitates less than $200 \mathrm{~mm}$ from June to September, around $300 \mathrm{~mm}$ in October and November, and peaks in December with about $500 \mathrm{~mm}$.

The farm was started as a monocrop rubber replanting with RRIM 600 cultivar planted in a spacing of $6 \mathrm{~m} \times 3 \mathrm{~m}$ on flat land in 2002. The rubber trees have been harvested, applying a tapping system of one-third spiral of tapping cut length and two-day tapping in three days since 2008. The heights of the rubber tree were around $18 \mathrm{~m}$, and the stem girths were average at 79 $\mathrm{cm}$ at the height of $170 \mathrm{~cm}$ from the ground. The associated plant, salacca palm, was intercropped in 2008 between the rubber rows with the same spacing as the rubber planting. As a result, the palm's growths were uniform, with the average height and width of their canopies of $3.6 \mathrm{~m}$ and $4.5 \mathrm{~m}$, respectively.

The experiment was designed in a randomized complete block design comprised of three fertilization treatments with three replications. Each replicated plot covered one row of ten rubber trees and adjacent two rows of the salacca palms. The treatments were formulated to compare the applications of two different organic soil amendments combined with mixed organic-inorganic fertilizer against the controlled application of conventional chemical fertilizer (Table 1).

Table 1

Summary of the three treatments of fertilizations

\begin{tabular}{|c|c|c|c|c|c|c|}
\hline \multirow{2}{*}{ Treatments } & \multicolumn{2}{|c|}{ Chemical fertilizer } & \multicolumn{2}{|c|}{ Organic fertilizer } & \multicolumn{2}{|c|}{ Organic soil amendment } \\
\hline & Types & $\begin{array}{l}\text { Application } \\
\text { rate }\end{array}$ & Types & $\begin{array}{c}\text { Application } \\
\text { rate }\end{array}$ & Types & $\begin{array}{l}\text { Application } \\
\text { rate }\end{array}$ \\
\hline $\mathrm{T} 1$ & $\begin{array}{l}\text { Compound } \\
\text { fertilizer } \\
(30-5-18)\end{array}$ & $\begin{array}{c}1 \mathrm{~kg} \text { tree }^{-1} \mathrm{y}^{-1} \\
\text { (3 times) }\end{array}$ & - & - & - & - \\
\hline $\mathrm{T} 2$ & $\begin{array}{l}\text { Compound } \\
\text { fertilizer } \\
(30-5-18)\end{array}$ & $\begin{array}{l}0.5 \mathrm{~kg} \text { tree }^{-1} \mathrm{y}^{-1} \\
\text { (3 times) }\end{array}$ & $\begin{array}{l}\text { Composted } \\
\text { cow manure }\end{array}$ & $\begin{array}{c}10 \mathrm{~kg} \\
\text { (3 times) }\end{array}$ & $\begin{array}{l}\text { Humic } \\
\text { acid }\end{array}$ & $\begin{array}{c}100 \mathrm{~mL} 20 \mathrm{~L}^{-1} \\
\text { water (3 times) }\end{array}$ \\
\hline $\mathrm{T} 3$ & $\begin{array}{l}\text { Compound } \\
\text { fertilizer } \\
(30-5-18)\end{array}$ & $\begin{array}{l}0.5 \mathrm{~kg} \text { tree }^{-1} \mathrm{y}^{-1} \\
(3 \text { times })\end{array}$ & $\begin{array}{l}\text { Composted } \\
\text { cow manure }\end{array}$ & $\begin{array}{c}10 \mathrm{~kg} \\
\text { (3 times) }\end{array}$ & Chitosan & $\begin{array}{c}100 \mathrm{~mL} 20 \mathrm{~L}^{-1} \\
\text { water (3 times) }\end{array}$ \\
\hline
\end{tabular}


In the control treatment (T1), chemical compound fertilizer 30-5-18 nitrogenphosphorus-potassium (N-P-K) was broadcasted at a rate of one kilogram per rubber tree per year between the rows of the rubber trees and the salacca palms in March, July, and November 2016. In the other treatments (T2 and T3), the chemical fertilizer mixed at a rate of $0.5 \mathrm{~kg}$ per rubber tree with 10 kilograms of composted cow manure was applied from April. Then, humic-acid soil amendment (HSA) prepared by mixing $100 \mathrm{~mL}$ of vermicompost-derived humic acid $(\mathrm{pH} 6.5,5 \%$ humic acid, 50\% organic matter, $5 \%$ total nitrogen, $2.5 \%$ total potassium, $0.06 \%$ total phosphorus, $0.25 \%$ calcium) with $20 \mathrm{~L}$ of water and sprayed on the soil between the rubber trees and the palms in T2 from May (Ruangkhanab \& Lim, 2005). Then, with the same application rate as the HSA treatment, $100 \mathrm{~mL}$ of the chitosan ( $\mathrm{pH} 5.5 \sim 6,6.5 \%$ organic carbon, $0.05 \%$ nitrogen, $0.01 \%$ phosphorus oxide, $0.01 \%$ potassium) mixed with $20 \mathrm{~L}$ of water was applied as the chitosan soil amendment (CSA) in T3 from May. All these fertilizations were applied three times with a third-monthly interval during the study period.

Soil organic matters (SOM) from soil depths of $0-20 \mathrm{~cm}$ and $21-40 \mathrm{~cm}$ of each plot were determined using Walkley-Black's titration method (FAO, 2020) in February 2016 and February 2017 to compare the SOM contents before and after treatments.

Changes in leaf area index (LAI) at the farm were monitored monthly by the hemispherical photography method from
June to December 2016. The hemispherical photos were taken vertically upward from $1.2 \mathrm{~m}$ above the ground at three different points in the inter-row between the rubber trees and the salacca palms at every treatment plot by using Nikon Coolpix 8400 camera (Nikon, Japan) with a fish-eye lens (Bianchi et al., 2017). The Gap Light Analyzer (GLA) software version 2.0 was used to analyze the fish-eye captured images.

Changes in fine root traits, notably fine root diameter (FRD) and fine root length density (FRLD) of both crops, were monitored in two layers of soil depths (0-20 $\mathrm{cm}$ and $21-40 \mathrm{~cm}$ ) by using the Prince of Songkla University (PSU) minirhizotron root scanner through $10 \mathrm{~cm}$ in diameter with $100 \mathrm{~cm}$ long of two acrylic access tubes per treatment plot installed with $45^{\circ}$ angle of slope in the soil (Saelim et al., 2019; Vamerali et al. 2011) between the rubber tree and the palm. Two months after installing the acrylic tubes, the root images were scanned monthly from June to December 2016. The scanned images were analyzed using the Rootfly software (version 2.0.2).

Latex samples were collected monthly from each plot to analyze the latex production expressed in dry rubber weight per tapping per tree $\left(\mathrm{g} \mathrm{tap}^{-1}\right.$ tree $\left.^{-1}\right)$. The collected samples were coagulated using formic acid and then dried at $70{ }^{\circ} \mathrm{C}$ for $16 \mathrm{~h}$ to calculate the dry weight of rubber content in the latex as recommended by ISO 126:2005. Productions of the salacca palms in yield per cluster and total yield per palm were recorded collectively at the end of the study period from randomly selected seven palms from each plot. 
The biochemical parameters of latex, namely sucrose (Suc) content, inorganic phosphorus $(\mathrm{Pi})$ content, and reduced thiols (R-SH) content, were measured monthly from latex samples taken from selected rubber trees of each treatment plot by following the latex micro-diagnosis method of the French Agricultural Research Centre for International Development (CIRAD). (Chantuma et al., 2011).

Data collected were analyzed with the $\mathrm{R}$ software (version 3.6.2) using a oneway analysis of variance (ANOVA). In addition, Duncan's multiple range tests were performed at $p \leq 0.05$ to compare the data pairs, and Pearson's linear correlation $(r)$ at $p \leq 0.05$ was applied in correlation analysis.

\section{RESULTS}

\section{Comparisons of SOM}

The higher content of SOM was found in the topsoil layer (0-20 cm depth). In comparison, the deeper soil layers had relatively lower organic matter content under all treatments after the experiment (Figure 1). Although all treatments increased the SOM in all layers of soil depth, the top layers under $\mathrm{T} 1$ and $\mathrm{T} 3$ showed remarkably higher soil organic matter contents. T3 increased the SOM in the topsoil layer by $80 \%$, followed by $\mathrm{T} 1$, with an increase of $38 \%$ after the experiment.

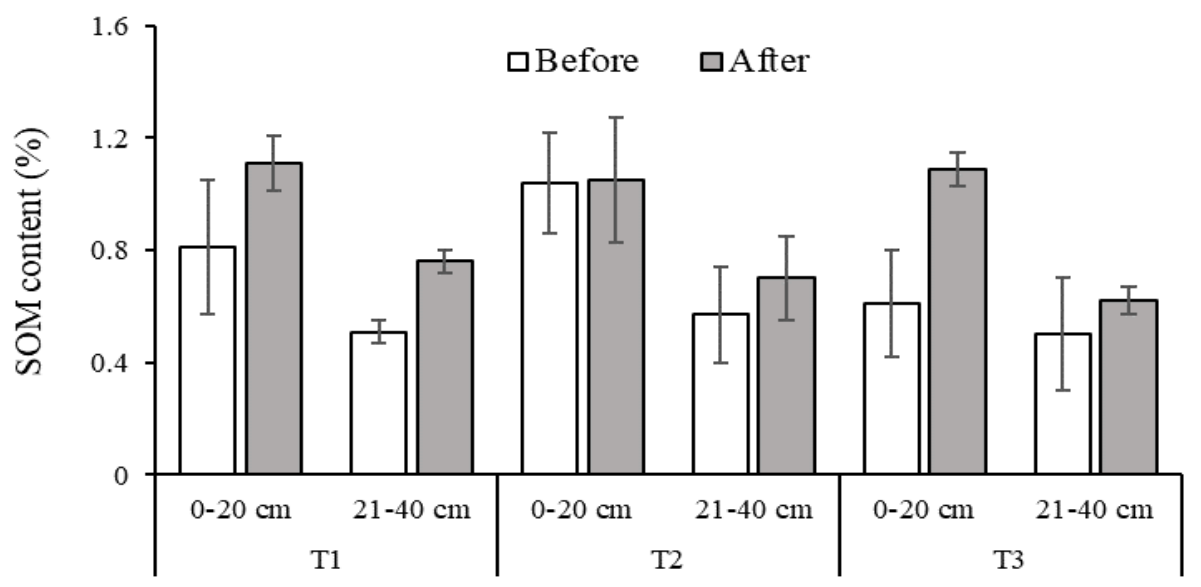

Figure 1. Comparison of soil organic matter (SOM) among the treatments before and after the experiment

\section{LAI of the Farm}

Although there were no significant differences in the LAIs among the treatments during the study, the changes followed a similar trend (Figure 2). The LAIs of the farm started increasing in July with just over 1.10 and reached their maximum values ranging between 1.50 and 1.71 in September. Then they decreased to their lowest values between 1.00 and 1.20 in October and 


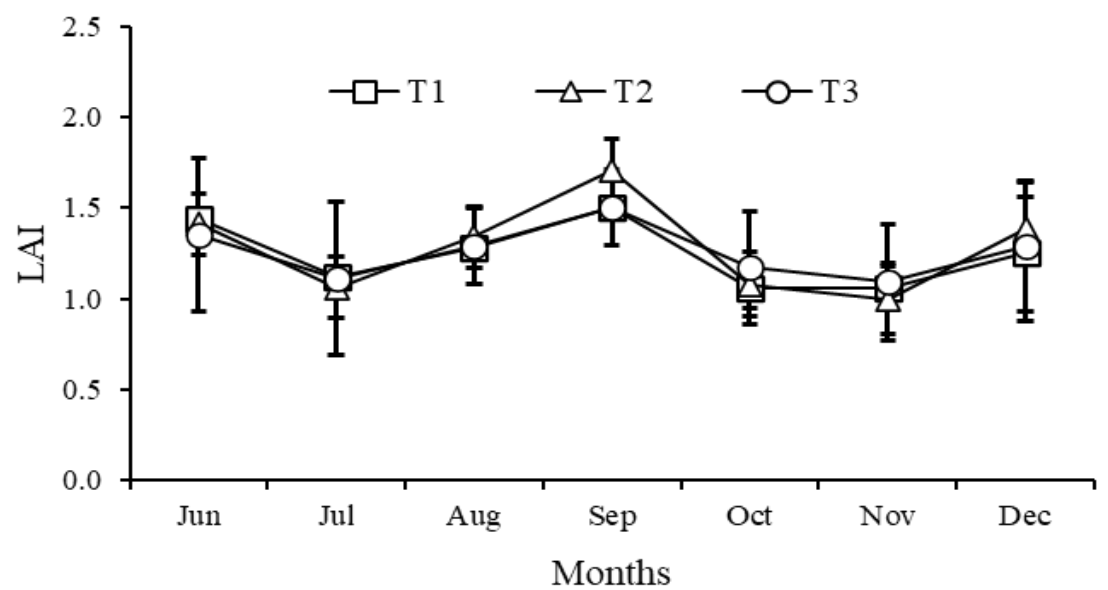

Figure 2. Changes in leaf area index (LAI) of the farm under the three treatments (from June to December 2016)

November, respectively. However, the LAI values of the farm increased back in the range of 1.29 and 1.39 in December.

\section{Fine Root Traits of the Rubber Tree}

FRDs of the rubber trees under T1 were found as the largest over those of the other treatments from June to September in both soil layers $(0-20 \mathrm{~cm}$ and $21-40 \mathrm{~cm})$ (Figure 3). In the soil depth of $21-40 \mathrm{~cm}$, the average size of the FRD under T1 was higher than that of $\mathrm{T} 2$ and $\mathrm{T} 3$ by $27 \%$ and $28 \%$, respectively (Figure 3B).

In terms of changes in FRLD (Figure 3 C), all treatments resulted in a stable trend ranging between 0.34 and $0.70 \mathrm{~cm} \mathrm{~cm}^{-2}$ in the topsoil layer during the study period. In the soil depth of 21-40 cm (Figure $3 \mathrm{D}$ ), the rubber trees under T2 were observed with the highest FRLD at over $1.44 \mathrm{~cm}$ $\mathrm{cm}^{-2}$ between July and October. After October, however, it decreased slightly with the densities of 1.46 and $1.09 \mathrm{~cm} \mathrm{~cm}^{-2}$ in November and December, respectively.

\section{Fine Root Traits of the Salacca Palm}

The fine roots of the salacca palm in the soil depth of 0-20 cm (Figure 4A) under T1 showed the largest diameter sizes ranged between 0.82 to $1.23 \mathrm{~cm}$, while the other treatments resulted in smaller sizes of the FRDs ranging between 0.67 and $0.95 \mathrm{~cm}$. In the soil depth of $21-40 \mathrm{~cm}$, the sizes of FRD under T1 were also larger than those under other treatments in July, August, September, and October (Figure 4 B).

Monthly changes of the FRLD of the salacca palm (Figure $4 \mathrm{C}$ ) in the soil depth of $0-20 \mathrm{~cm}$ were stable between 0.20 and $0.38 \mathrm{~cm} \mathrm{~cm}^{-2}$ and did not show a significant difference during the study period. However, in 21-40 cm soil depth, T3 resulted in the highest FRLD in July, October, November, and December with $0.60,0.64,0.46$, and $0.40 \mathrm{~cm}$, respectively (Figure $4 \mathrm{D}$ ). 

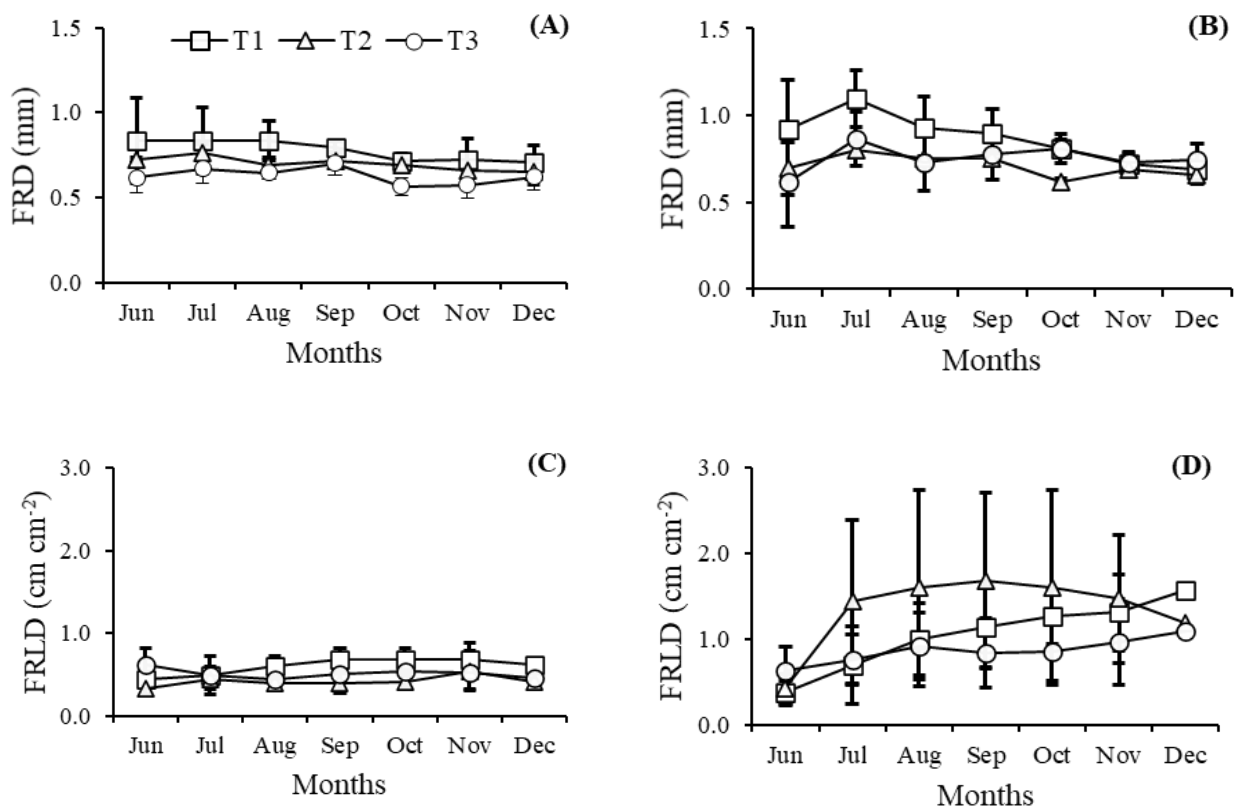

Figure 3. Monthly changes in fine root traits of the rubber tree: fine root diameter (FRD) at the soil depths of (A) $0-20 \mathrm{~cm}$ and (B) $21-40 \mathrm{~cm}$; fine root length density (FRLD) at the soil depth of (C) 0-20 cm and (D) 21-40 cm (from June to December 2016)
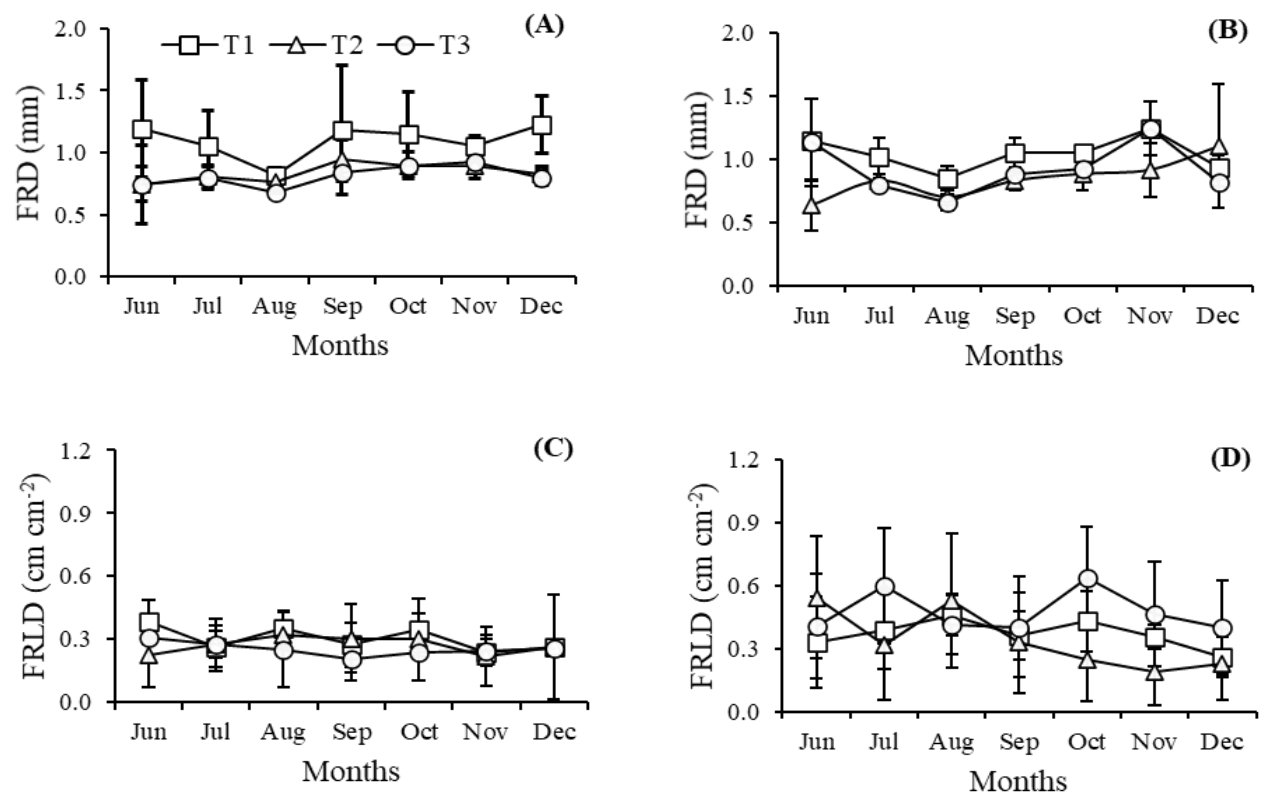

Figure 4. Monthly changes in fine root traits of the salacca plam: fine root diameter (FRD) at the soil depths of (A) $0-20 \mathrm{~cm}$ and (B) $21-40 \mathrm{~cm}$; fine root length density (FRLD) at the soil depth of (C) $0-20 \mathrm{~cm}$ and (D) $21-40 \mathrm{~cm}$ (from June to December 2016) 


\section{Latex Production}

Although there were no significant differences among the latex productions under the different treatments, the latex productions varied with different seasons (Figure 5). At the beginning of the rainy season, the productions under all treatments dropped their yields from about $60 \mathrm{~g} \mathrm{tap}^{-1}$ tree ${ }^{-1}$ in June to less than $40 \mathrm{~g} \mathrm{tap}^{-1}$ tree $^{-1}$ in July. Then, the production increased to the highest level between 73 and $80 \mathrm{~g} \mathrm{tap}^{-1}$ tree $^{-1}$ in September. However, all treatments showed less production with around $30 \mathrm{~g} \mathrm{tap}^{-1}$ tree $^{-1}$ in November. Finally, in December, the productions under $\mathrm{T} 1, \mathrm{~T} 2$, and $\mathrm{T} 3$ surged back, respectively, with 80,65 , and $50 \mathrm{~g} \mathrm{tap}^{-1}$ tree $^{-1}$. The result of Pearson's linear correlation $(r=+0.6024)$ at $p \leq 0.05$ confirmed a positive correlation between the monthly changes of the LAIs and the latex production under all treatments (Figure 6).

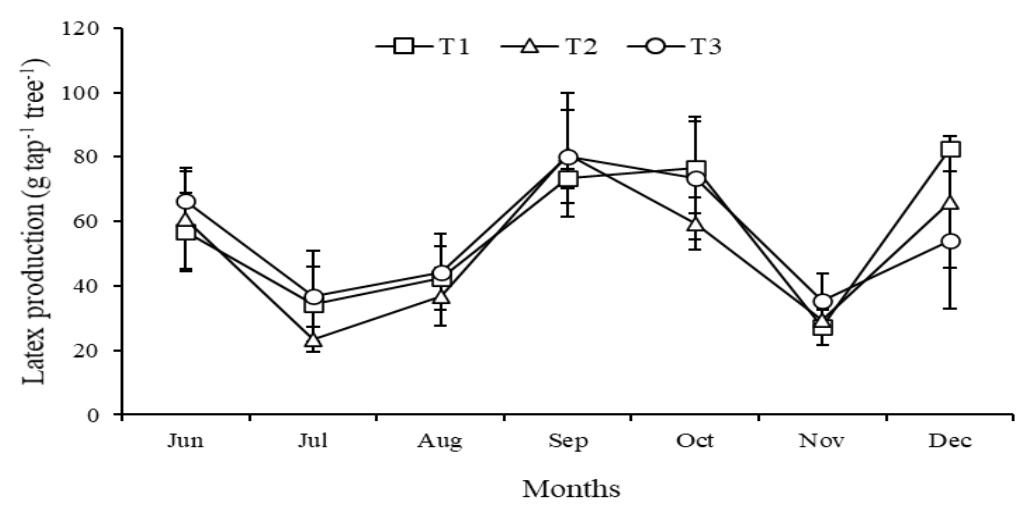

Figure 5. Monthly changes in average daily production of latex $\left(\mathrm{g} \mathrm{tap}^{-1} \operatorname{tre}^{-1}\right)$ under the treatments (from June to December 2016)

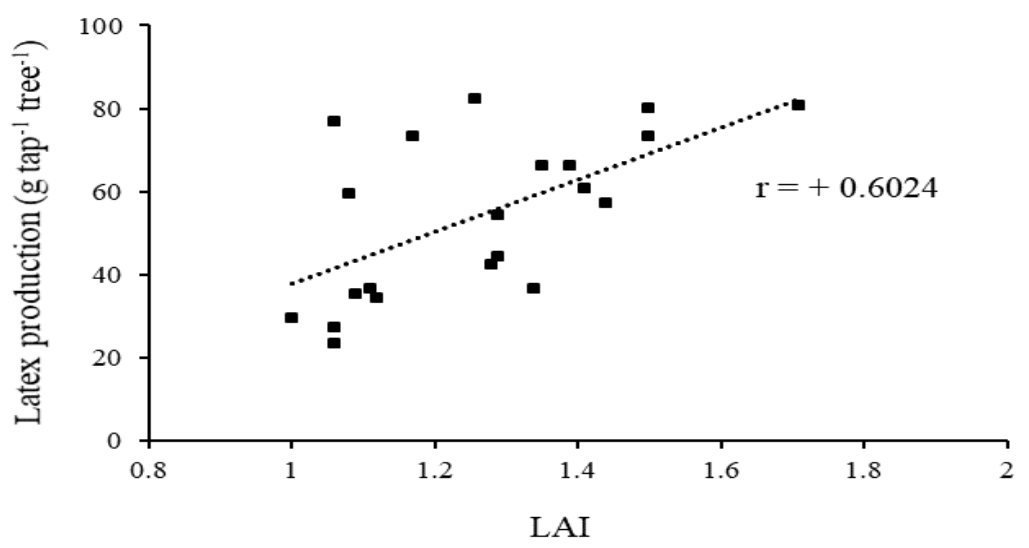

Figure 6. Relationship between the changes of LAI and latex productions 


\section{Latex Biochemical Composition}

Suc contents of all treatments decreased gradually between July and October, except that of T2 showed a peak at $13.66 \mathrm{mM}$ in August (Figure 7 A). The Suc contents of T1 and $\mathrm{T} 2$ reached their minimum levels of 1.79 and $2.43 \mathrm{mM}$, respectively, in November. However, T3 showed an upward trend in November after its lowest level of $4.65 \mathrm{mM}$ in October. In December, the Suc content under $\mathrm{T} 3$ reached $9.77 \mathrm{mM}$ as the highest level in that month, followed by $\mathrm{T} 2$ and $\mathrm{T} 1$ with 6.76 and $3.53 \mathrm{mM}$, respectively.

$\mathrm{Pi}$ content under $\mathrm{T} 2$ decreased from $21.33 \mathrm{mM}$ in June to $10.52 \mathrm{mM}$ in July (Figure $7 \mathrm{~B}$ ). The contents under $\mathrm{T} 1$ and T3, however, were stable between 10.54 and
$12.61 \mathrm{mM}$ from June to September. Between September and November, the Pi contents of all treatments increased, and that of T3 was the highest with $30.59 \mathrm{mM}$ followed by that of $\mathrm{T} 2$ and T1, respectively, in November. Then, the Pi contents under all treatments decreased again in December.

$\mathrm{R}-\mathrm{SH}$ levels of the treatments were different in June as that of T3 was at $0.43 \mathrm{mM}$ as the highest, followed by $\mathrm{T} 1$ and $\mathrm{T} 2$ with $0.30 \mathrm{mM}$ and $0.15 \mathrm{mM}$, respectively (Figure 7C). After July, however, all treatments increased slightly until November, and the R-SH level under T3 was the highest in November. Then in December, the R-SH level of all treatments declined under 0.30 $\mathrm{mM}$.
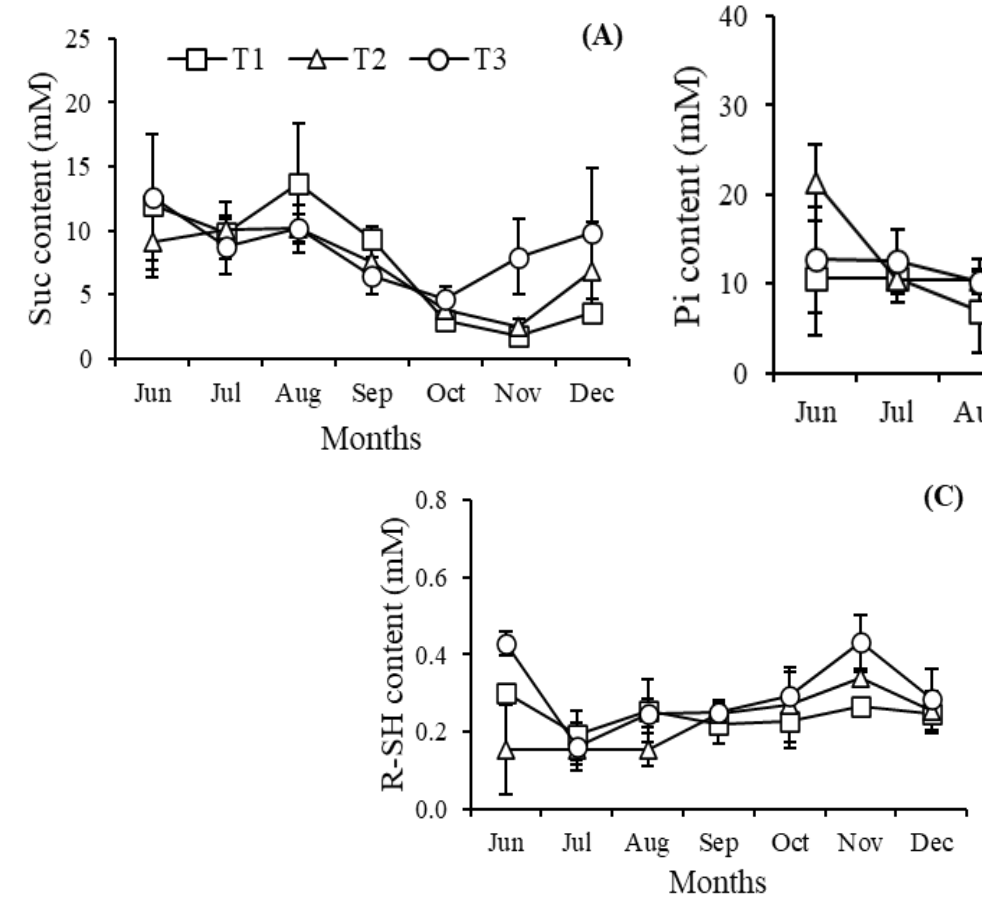

Figure 7. Monthly changes in biochemical composition (A) sucrose - Suc content; (B) inorganic phosphorus - Pi content; (C) reduced thiols - R-SH content of latex under the treatments (from June to December 2016)

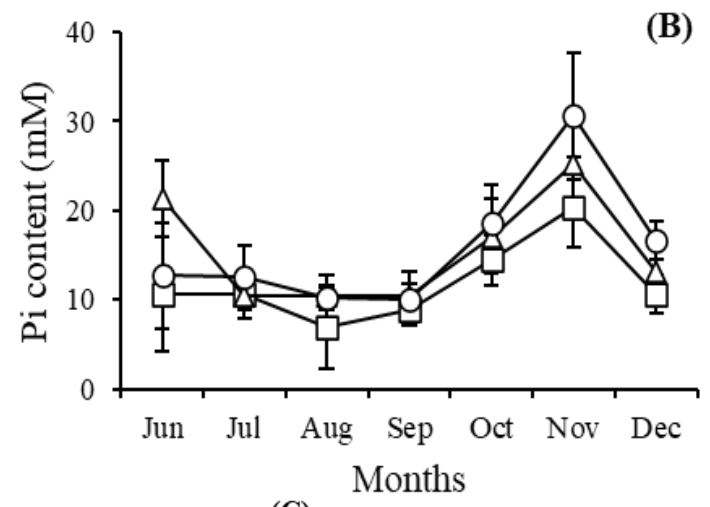

C) 


\section{Salacca Palm Production}

The salacca productions were significantly different among the treatments in yield per cluster, and total yield per palm (Table 2) as $\mathrm{T} 2$ delivered the highest weight with $1.60 \mathrm{~kg}$ cluster $^{-1}$ followed by T3 with $1.33 \mathrm{~kg}$ cluster $^{-1}$ while that of $\mathrm{T} 1$ was the lowest at $0.77 \mathrm{~kg}$ cluster ${ }^{-1}$. Likewise, the total yields $\left(\mathrm{kg} \mathrm{palm}^{-1}\right)$ of $\mathrm{T} 2$ and $\mathrm{T} 3$ were $145 \%$ and $72 \%$, respectively, higher than $\mathrm{T} 1$.

Table 2

Production of the salacca palms among the treatments

\begin{tabular}{lcc}
\hline \multirow{2}{*}{ Treatment } & \multicolumn{2}{c}{ Yields of the salacca palm } \\
\cline { 2 - 3 } & kg cluster $^{-1}$ & $\mathrm{~kg} \mathrm{palm}^{-1}$ \\
\hline T1 & $0.77 \pm 0.05^{\mathrm{c}}$ & $2.50 \pm 0.89^{\mathrm{c}}$ \\
T2 & $1.60 \pm 0.09^{\mathrm{a}}$ & $6.13 \pm 1.10^{\mathrm{a}}$ \\
T3 & $1.33 \pm 0.21^{\mathrm{ab}}$ & $4.38 \pm 1.50^{\mathrm{b}}$ \\
\hline
\end{tabular}

Note. Different lower-case letters in the same column are significantly different at $p \leq 0.05$ by Duncan's multiple range test

\section{DISCUSSION}

\section{Soil Fertility Improvement}

The study observed that the plot amended with CSA had a maximum level of SOM content in the topsoil layer. The result was likely due to the enzymatic soil microbial activities improved by CSA, enhancing the decomposition process of organic materials in the topsoil layer (Sawaguchi et al., 2015). Besides, the soil microbial population increased and decomposed themselves, resulting in a higher level of organic matter in the soil. The higher content of SOM is an indicator of healthy soil with efficient infiltration and water-holding capacity, thus higher nutrient availability (C. Chen et al., 2017; Nannipieri et al., 2017).

\section{Development of the Fine Root Traits}

It was noticed that the FRD of both crops under $\mathrm{T} 1$ showed a larger size in both soil layers in general. It signaled high limitation in the movements of water and nutrients from the soil to the roots resulting in low vegetative growth and productivity (Comas et al., 2013). Conversely, roots with smaller diameters have greater hydraulic conductivity and tolerate drought conditions (Henry et al., 2012). The small diameters of the fine roots under $\mathrm{T} 2$ and $\mathrm{T} 3$ reflected the better performance of the root functions because of the higher availability of nutrients and water in the soil under the organic soil amendment application (du Jardin, 2015).

In all treatments, the FRLD of rubber trees in the soil depth of $21-40 \mathrm{~cm}$ showed upward trends once the rainy season began but in the soil depth of 0-20 cm. It indicated that the development of rubber fine roots in the soil depth of $21-40 \mathrm{~cm}$ was more 
responsive to the rainfall than the topsoil layer. A study conducted in the same province by Saelim et al. (2019) also found that the fine roots of the 16-yearold rubber, particularly in the soil depth 20-30 cm developed at a higher rate in the rainy season. The result was consistent with Maeght et al.'s (2015) finding in north-eastern Thailand that the fine rubber roots within the soil depth of $2 \mathrm{~m}$ exhibited higher root emergences during the rainy season. Among the treatments, the rubber trees treated with the HSA showed higher FRLD in 21-40 cm soil depth from July to October. Wasson et al. (2012) remarked that a root system with greater FRLD in deeper soil could uptake water and nutrients at high efficiency. Cahyo et al. (2014) reported that root growth and performance were more obvious than other vegetative parts under the HSA. It could serve as auxin and promote cell enlargement by stimulating the cell wall loosening leading to greater vegetative growth (Jindo et al., 2012). However, it was noticed that the FRLDs of the salacca palm were higher under the CSA in the soil depth of 21-40 cm. CSA could enhance cation properties and water holding capacity in the soil, thereby more significant development of fine roots resulting in better nutrient uptakes and improved crop yield (Sharp, 2013).

\section{The Vegetative Growth and Production of the Crops}

The study confirmed a positive relationship between the LAIs and latex production under all treatments. At the beginning of the rainy season, in July and August, latex harvest (tapping) activities could not be carried out regularly due to the disturbance of uneven raining patterns resulted in yield drops in all treatments. The latex productions under all treatments were at maximum levels in September, while leaves in the rubber canopy reached the ultimate growth stage. Since the planted cultivar, RRIM 600 clone, is susceptible to phytophthora leaf fall disease (Krishnan et al., 2019), which occurs typically during the rainy season, the rubber trees in the farm were attacked by the disease, thus fewer values of LAI in November. In the meantime, it was observed that the latex yields under all treatments dropped from their maximum yields. Leaf area is a functional part of a tree's photosynthesis and determines photosynthetic efficiency, reflecting sucrose synthesis (Weraduwage et al., 2015). Since natural rubber is a photosynthesis product of $H$. brasiliensis through sucrose synthesis in non-photosynthesis laticiferous tissue, the leaf area of the rubber tree influences latex yield and dry mass production of rubber (Zhu et al., 2018).

Regarding salacca production, the treatments of the integrated fertilizations delivered significantly higher yields compared to that of the chemical fertilization. It was contributed by the beneficial effects of the integrated fertilization that organic fertilizer and organic soil amendments could promote inorganic fertilization effectiveness, thereby more extended availability of nutrients in the soil (Wu et al., 2020). In addition, it could improve the soil's physical 
properties such as cation exchange capacity and water holding capacity, enhancing root proliferation and the root system's nutrient uptake functions, resulting in higher crop yield (Sharp, 2013).

In addition, it was noticed that yields per cluster in all treatments were apparently higher than the average yield of around 0.6 $\mathrm{kg}$ per cluster of conventional salacca-fruit intercropping (Sumantra \& Martiningsih, 2018). In rubber-based intercropping, the canopy of mature rubber trees reduces extreme temperature and intense irradiance, improving the adaptability of understorey plants especially shade-required species like salacca palm (Montagnini, 2011; Rappaport \& Montagnini, 2014). Along with the favorable weather conditions, the co-existence of the different canopy architectures, like the combination of rubber trees and salacca palms, enhancing light interception and distribution in the farm contributes to a greater photosynthetic rate resulting in yield improvement of the crops (Sumantra et al., 2012; Tang et al., 2019; Xianhai et al., 2012).

\section{Less Physiological Stress of the Rubber Tree}

It was observed that all treatments showed higher Suc content, lower Pi content, and lower yields at the beginning of the rainy season after the dry season. It reflected low metabolic utilization or insufficient conversion of sucrose into cis-isoprene rubber molecules in the latex resulting in higher Suc content remaining and fewer rubber particles in the latex (Purwaningrum et al., 2015). Then, in September and October, the yields of all treatments were at a high level with an elevation of the Pi contents. It indicated the high metabolism of the laticiferous contributed by the regular tapping activity (Atsin et al., 2016). However, in November, the Suc contents under T1 and T2 declined to the lowest level, and their productions also plunged to less than $30 \mathrm{~g} \mathrm{tap}^{-1}$ tree $^{-1}$ at that month, reflecting that the rubber trees were exhausted with the shortage of sucrose supply because of the effects of the high-frequency latex harvest practice (overexploitation) and the occurrences of the abnormal leaf fall disease. A study by Obouayeba et al. (2011) indicated that low sucrose content less than around 3-4 $\mathrm{mM}$ associated with yield drops reflected the initial symptom of the tree stress with physiological disorders in the laticiferous system leading to tapping panel dryness. The intensity of physiological stress could vary between rubber clones due to their different sugar loading capacities (Gohet et al., 2015). In addition, the abnormal leaf fall disease destructed the photosynthesis functions, thereby reducing the Suc's sufficient supply, resulting in the yield drop. However, the Suc content, the Pi content, and the R-SH content under T3 was at a high level, and the yield in $\mathrm{T} 3$ remained over $30 \mathrm{~g}^{\mathrm{tap}^{-1}}$ tree $^{-1}$ and was not as low as that of the others. These physiological responses reflected less physiological stress of the laticiferous system (Sainoi et al., 2017) and the lesser effect of the phytophthora attack under T3 compared to those of the other treatments. It was likely to be the CSA's antimicrobial 
effect since its application restrained and slowed down the growth of the pathogen by enhancing the response of the plant's immune system (Sunpapao \& Pornsuriya, 2014).

\section{CONCLUSION}

The study observed that both HSA and CSA treatments improved the fine root trait developments of the crops, particularly in the soil depths of $21-40 \mathrm{~cm}$. The fine rubber roots were responsive under the HSA, while the fine root growths of the salacca showed more significance under the CSA. It was found that a positive correlation between the average yields of rubber and the LAI in the farm. The study highlighted that the advantages of CSA on rubber trees that its application improved the tree physiological status. Thus, the latex biochemical composition levels and the daily yield were maintained under the CSA application during the intensive latex harvest practices and the phytophthora leaf disease attack. A significant increase in soil organic matter under the CSA treatment was also advantageous.

The higher yields per cluster of salacca trees in all treatments compared to other conventional salacca farms indicated the beneficial effect of the rubber-salacca combination. In addition, the significantly higher yields of salacca under the HSA and CSA further approved the effect of the integrated fertilizations.

The study highlighted the complementarity effect resulting from harmonious interactions between the integrated fertilization and agroecosystem components of the rubber-salacca intercropping. Therefore, it is suggested that the mixed organic-inorganic fertilization with organic soil amendments could be utilized in rubber-based intercropping as effectively integrated fertilization to reduce the usage of chemical fertilizer without affecting the crop yields.

\section{ACKNOWLEDGEMENTS}

The study was funded by the Natural Rubber Innovation Research Institute and Thailand's Education Hub for ASEAN Countries (THE-AC), Graduate School, Prince of Songkla University scholarship under project number NAT581136S. The authors thank the farm's owner for allowing this experimental study.

\section{REFERENCES}

Adou, C. Y. B., Atsin, O. J. G., Essehi, J. L., Ballo, K. E., Soumahin, F. E., Obouayeba, P. A., Kouakou, H. T., \& Obouayeba, S. (2017). Latex micro diagnosis, modern management tool of rubber plantation of clones with moderate metabolism GT 1, RRIC 100 and BPM 24. Journal of Applied Biosciences, 121, 12098-12109. https://doi. org/10.4314/jab.v121i1.1

Atsin, G. J. O., Soumahin, E. F., Kouakou, T. H., Elabo, A. E. A., Okoma, K. M., \& Obouayeba, S. (2016). Agronomic potential of some rubber tree clones (Hevea brasiliensis) of the fast metabolic activity class in the absence of hormonal stimulation in southwestern of Côte d'Ivoire. American Journal of Experimental Agriculture, 13(4), 1-13. https://doi.org/10.9734/ AJEA/2016/26930 
Bianchi, S., Cahalan, C., Hale, S., \& Gibbons, J. M. (2017). Rapid assessment of forest canopy and light regime using smartphone hemispherical photography. Ecology and Evolution, 7(24), 10556-10566. https://doi.org/10.1002/ece3.3567

Buyukkeskin, T., Akinci, S., \& Eroglu, A. E. (2015). Effects of humic acid on root development and nutrient uptake of Vicia faba L. (broad bean) seedlings grown under aluminum toxicity. Communications in Soil Science and Plant Analysis, 46(3), 277-292. https://doi.org/10.108 0/00103624.2014.969402

Bybee-Finley, K. A., \& Matthew, R. R. (2018). Advancing intercropping research and practices in industrialized agricultural landscapes. Agriculture, 8(6), 80. https://doi.org/10.3390/ agriculture 8060080

Cahyo, A. N., Ardika, R., Saputra, J., \& Wijaya, T. (2014). Acceleration on the growth of rubber planting materials by using folia application of humic acid. Agrivita, 36(2), 112-119. https://doi. org/10.17503/agrivita.v36i2.397

Chantuma, P., Lacote, R., Leconte, A., \& Gohet, E. (2011). An innovative tapping system, the double cut alternative, to improve the yield of Hevea brasiliensis in Thai rubber plantations. Field Crops Research, 121(3), 416-422. https://doi. org/10.1016/j.fcr.2011.01.013

Chen, C., Liu, W., Jiang, X., \& Wu, J. (2017). Effects of rubber-based agroforestry systems on soil aggregation and associated soil organic carbon: Implication for land use. Geoderma, 299, 13-24. https://doi.org/10.1016/j.geoderma.2017.03.021

Chen, Y. C., Yuan, S., Liu, H., Chen, Z., Zhang, Y., \& Zhang, H. (2016). A combination of chitosan and chemical fertilizers improves growth and disease resistance in Begonia hiemalis Fotsch. Horticulture, Environment, and Biotechnology, 57, 1-10. https://doi.org/10.1007/s13580-0160119-4
Christophe, A. B. Y., Mathurin, O. K., Pacome, O. A., Olivier, A. G., Kouadio, B. E., Jean-Lopez, E., Jean, W. P., Francis, S. E., Hilaire, K. T., \& Samuel, O. (2018). Latex micro diagnosis, modern management tool of rubber plantations of clones with active or rapid metabolism IRCA 18, IRCA 130, PB 235, PB 260 and PB 330. European Scientific Journal, 14(3), 385. https:// doi.org/10.19044/esj.2018.v14n3p385

Comas, L. H., Becker, S. R., Cruz, V. M., Byrne, P. F., \& Dierig, D. A. (2013). Root traits contributing to plant productivity under drought. Frontiers in Plant Science, 4, 442. https://doi.org/10.3389/ fpls.2013.00442

Dharmakeerthi, R. S., Chandrasiri, J. A. S., \& Edirimanne, V. U. (2013). Humic acid based liquid organic fertilizer improved the growth of nursery and immature rubber plants grown in Boralu soil series. Journal of the Rubber Research Institute of Sri Lanka, 93, 1-15. http:// doi.org/10.4038/jrisl.v93i0.1863

Doungmusik, A., \& Sdoodee, S. (2012). Enhancing the latex productivity of Hevea brasiliensis clone RRIM 600 using ethylene stimulation. Journal of Agricultural Technology, 8(6), 2033-2042.

du Jardin, P. (2015). Plant biostimulants: Definition, concept, main categories and regulation. Scientia Horticulturae, 196, 3-14. https://doi. org/10.1016/j.scienta.2015.09.021

Food and Agriculture Organization of the United Nations. (2016). Guidelines for the management of plant nutrients and their sources. In R. N. Roy, A. Finck, G. J. Glair, \& H. L. S. Tandon (Eds.), Plant nutrition for food security: A guide for integrated nutrient management (pp. 141-192). FAO.

Food and Agriculture Organization of the United Nations. (2020). Standard operating procedure for soil organic carbon. Walkley-Black method: Titration and colorimetric method. FAO. 
Gohet, E., Cavaloc, E., Cardoso, S., Cairo, I., Garcia, D., Rivano, F., Lacote, R., \& Lesturgez, G. (2015). A first physiological assessment of latex clonal metabolic typology and rubber yield potential of "CMS" rubber tree clones. In Proceedings of International Rubber Conference (pp. 287-294). Agriculture Publishing House. https://doi.org/10.13140/RG.2.1.3007.4328

Henry, A., Cal, A. J., Batoto, T. C., Torres, R. O., \& Serraj, R. (2012). Root attributes affecting water uptake of rice (Oryza sativa) under drought. Journal of Experimental Botany, 63(13), 47514763. https://doi.org/10.1093/jxb/ers150

Hougni, D. J. M., Chambon, B., Penot, E., \& Promkhambut, A. (2018). The household economics of rubber intercropping during the immature period in Northeast Thailand. Journal of Sustainable Forestry, 37(8), 787-803. https:// doi.org/10.1080/10549811.2018.1486716

Jindo, K., Aparecida, M., Navarro, E. C., PerezAlfocea, F., Hernandez, T., Garcia, C., Aguiar, N. O., \& Canellas, L. P. (2012). Root growth promotion by humic acids from composted and non-composted urban organic wastes. Plant Soil, 353, 209-220. https://doi.org/10.1007/s11104011-1024-3

Jongrungrot, V., Thungwa, S., \& Snoeck, D. (2014). Tree-crop diversification in rubber plantations to diversify sources of income for small-scale rubber farmers in Southern Thailand. Bois et Forets des Tropiques, 68(321), 21-32. https:// doi.org/10.19182/bft2014.321.a31214

Krishnan, A., Joseph, L., \& Roy, C. B. (2019). An insight into Hevea - Phytophthora interaction: The story of Hevea defense and Phytophthora counter defense mediated through molecular signalling. Current Plant Biology, 17, 33-41. https://doi.org/10.1016/j.cpb.2018.11.009

Langenberger, G., Cadish, G., Martin, K., Min, S., \& Waibel, H. (2017). Rubber intercropping: A viable concept for the $21^{\text {st }}$ century?. Agroforestry
Systems, 91, 577-596. https://doi.org/10.1007/ s10457-016-9961-8

Li, Y., Fang, F., Wei, J., Wu, X., Cui, R., Li, G., Zheng, F., \& Tan, D. (2019). Humic acid fertilizer improved soil properties and soil microbial diversity of continuous cropping peanut: A threeyear experiment. Scientific Reports, 9, 12014. https://doi.org/10.1038/s41598-019-48620-4

Maeght, J. L., Gonkhamdee, S., Clement, C., Isarangkool Na Ayutthaya, S., Stokes, A., \& Pierret, A. (2015). Seasonal patterns of fine root production and turnover in a mature rubber tree (Hevea brasiliensis Mull. Arg.) standdifferentiation with soil depth and implications for soil carbon stocks. Frontiers in Plant Science, 6, 1022. https://doi.org/10.3389/fpls.2015.01022

Montagnini, F. (2011). Can tree plantations serve as catalysts of secondary forest succession?. In F. Montagnini \& C. Finney (Eds.), Restoring degraded landscapes with native species in Latin America (pp. 3-28). Nova Science Publishers.

Nannipieri, P., Ascher, J., Ceccherini, M. T., Landi, L., Pietramellara, G., \& Renella, G. (2017). Microbial diversity and soil functions. European Journal of Soil Science, 68(1), 12-26. https://doi. org/10.1111/ejss.4_12398

National Statistical Office. (2013). Executive summary: 2013 Agricultural census, southern region. National Statistical Office.

Obouayeba, S., Soumahin, E. F., Okoma, K. M., Boko, A. M. C. K., Dick, K. E., \& Lacote, R. (2011). Relationship between tapping intensity and tapping panel dryness susceptibility of some clones of Hevea brasiliensis in Southwestern Côte d'Ivoire. Agriculture and Biology Journal of North America, 2(8), 1151-1159. https://doi. org/10.5251/abjna.2011.2.8.1151.1159

Purwaningrum, Y., Asbur, Y., \& Junaidi. (2019). Latex quality and yield parameters of Hevea brasiliensis (Willd. ex A. Juss.) Müll. Arg. clone PB 260 for different tapping and stimulant 
application frequencies. Chilean Journal of Agricultural Research, 79(3), 347-355. https:// doi.org/10.4067/S0718-58392019000300347

Purwaningrum, Y., Napitupulu, J. A., Siregar, T. H. S., \& Hanum, C. (2015). Histology and physiology of BPM 1 clones with different exploitation systems. International Journal of Sciences: Basic and Applied Research, 21, 138-148.

Rappaport, D., \& Montagnini, F. (2014). Tree species growth under a rubber (Hevea brasiliensis) plantation: Native restoration via enrichment planting in southern Bahia, Brazil. New Forests, 45, 715-732. https://doi.org/10.1007/s11056014-9433-9

Romyen, A., Sausue, P., \& Charenjiratragul, S. (2018). Investigation of rubber-based intercropping system in Southern Thailand. Kasetsart Journal of Social Sciences, 39(1), 135-142. https://doi. org/10.1016/j.kjss.2017.12.002

Ruangkhanab, M., \& Lim, M. (2005). Effect of chemical application on vegetative growth of longkong. Songklanakarin Journal of Science and Technology, 27(3), 629-868.

Saelim, S., Sdoodee, S., \& Chiarawipa, R. (2019). Monitoring seasonal fine root dynamics of Hevea brasiliensis clone RRIM 600 in Southern Thailand using minirhizotron technique. Songklanakarin Journal of Science and Technology, 41(2), 341348. https://doi.org/10.14456/sjst-psu.2019.43

Sainoi, T., Sdoodee, S., Lacote, R., \& Gohet, E. (2017). Low frequency tapping systems applied to young-tapped trees of Hevea brasiliensis (Willd. ex A. Juss.) Müll. Arg. in Southern Thailand. Agriculture and Natural Resources, 51(4), 268-272. https://doi.org/10.1016/j. anres.2017.03.001

Sawaguchi, A., Ono, S., Oomura, M., Inami, K., Kumeta, Y., Honda, K., Sameshima-Saito, R., Sakamoto, K., Ando, K., \& Saito, A. (2015). Chitosan degradation and associated changes in bacterial community structures in two contrasting soils. Soil Science and Plant Nutrition, 61(3), 471-480. https://doi.org/10.1080/00380768.20 14.1003965

Selladurai, R., \& Purakayastha, T. J. (2016). Effect of humic acid multinutrient fertilizers on yield and nutrient use efficiency of potato. Journal of Plant Nutrition, 39(7), 949-958. http://doi.org/1 0.1080/01904167.2015.1109106

Sharp, R. G. (2013). A review of the applications of chitin and its derivatives in agriculture to modify plant microbial interactions and improve crop yields. Agronomy, 3(4), 757-793. https://doi. org/10.3390/agronomy3040757

Sumantra, I. K., \& Martiningsih, N. G. E. (2018). The agroecosystem of Salak Gulapasir (Salacca zalacca var. Amboinensis) in new development areas in Bali. https://www.researchgate.net/ publication/342923683_The_Agroecosystem of_Salak_Gulapasir_Salacca_zalacca_var_ amboinensis_in_New_Development_Areas in_Bali

Sumantra, I. K., Ashari, S., Wardiyati, T., \& Suryanto, A. (2012). Diversity of shade trees and their influence on the microclimate of agro-ecosystem and fruit production of Gulapasir salak (Salacca zalacca var. Amboinensis) fruit. International Journal of Basic and Applied Sciences, 12(6), 214-221.

Sunpapao, A., \& Pornsuriys, C. (2014). Effects of chitosan treatments on para rubber leaf fall disease caused by Phytophthora palmivora Butler - A laboratory study. Songklanakarin Journal of Science and Technology, 36(5), 507-512.

Tang, L., Yin, D., Chen, C., Yu, D., \& Han, W. (2019). Optimal design of plant canopy based on light interception: A case study with loquat. Frontiers in Plant Science, 10, 364. https://doi. org/10.3389/fpls.2019.00364 
Umami, I. M., Kamarudin, K. N., Hermansah, \& Abe, S. S. (2019). Does soil fertility decline under smallholder rubber farming? The case of a West Sumatran lowland in Indonesia. Japan Agricultural Research Quarterly, 3(4), 279-297. https://doi.org/10.6090/jarq.53.279

Vamerali, T., Bandiera, M., \& Mosca, G. (2011). Minirhizotrons in modern root studies. In $\mathrm{S}$. Mancuso (Ed.), Measuring roots as update approach (pp. 341-361). Springer. https://doi. org/10.1007/978-3-642-22067-8 17

Vrignon-Brenas, S., Gay, F., Ricard, S., Snoeck, D., Perron, T., Mareschal, L., Laclau, J., Gohet, E., \& Malagoli, P. (2019). Nutrient management of immature rubber plantations. A review. Agronomy for Sustainable Development, 39, 11. https://doi.org/10.1007/s13593-019-0554-6

Wasson, A. P., Richards, R. A., Chatrath, R., Misra, S. C., Prasad, S. V. S., Regetzke, G. J., Kirkegaard, J. A., Christopher, J., \& Watt, M. (2012). Traits and selection strategies to improve root systems and water uptake in water-limited wheat crops. Journal of Experimental Botany, 63(9), 34853498. https://doi.org/10.1093/jxb/ers111
Weraduwage, S. M., Chen, J., Anozie, F. C., Morales, A., Weise, S. E., \& Sharkey, T. D. (2015). The relationship between leaf area growth and biomass accumulation in Arabidopsis thaliana. Frontiers in Plant Science, 6, 167. https://doi. org/10.3389/fpls.2015.00167

Wu, L., Jiang, Y., Zhao, F., He, X., Liu, H., \& Yu, K. (2020). Increased organic fertilizer application and reduced chemical fertilizer application affect the soil properties and bacterial communities of grape rhizosphere soil. Scientific Reports, 10, 9568. https://doi.org/10.1038/s41598-02066648-9

Xianhai, Z., Mingdao, C., \& Weifu, L. (2012). Improving planting pattern for intercropping in the whole production span of rubber tree. African Journal of Biotechnology, 11(34), 8484-8490. https://doi.org/10.5897/AJB11.3811

Zhu, J., Qi, J., Fang, Y., Xiao, X., Li, J., Lan, J., $\&$ Tang, C. (2018). Characterization of sugar contents and sucrose metabolizing enzymes in developing leaves of Hevea brasiliensis. Frontiers in Plant Science, 9, 58. https://doi. org/10.3389/fpls.2018.00058 